\title{
DRD2 1 Allele
}

National Cancer Institute

\section{Source}

National Cancer Institute. DRD2 1 Allele. NCI Thesaurus. Code C19799.

Human DRD2 Gene at 11q23 encodes Dopamine Receptor D2, a G-protein coupled receptor that inhibits adenylyl cyclase activity. Missense mutation in DRD2 causes myoclonus dystonia; other mutations have been associated with schizophrenia. Alternative splicing results in two different isoforms. A third variant has been described, but it has not been determined whether this form is normal or due to aberrant splicing. Different alleles are associated with increased incidence of substance abuse. The A1 allele has been associated with alcoholism. (NCl) 